\title{
Bioconversions of olive oil mill wastewaters blends
}

\author{
Soupioni M. , Drenogianni K. and Balamatsi M. \\ Department of Chemistry, University of Patras, GR-26504 Patras, Greece \\ Received: 29/04/2018, Accepted: 10/10/2018, Available online: 15/10/2018 \\ *to whom all correspondence should be addressed: m.soupioni@chemistry.upatras.gr \\ https://doi.org/10.30955/gnj.002738
}

\section{Abstract}

The ability of the anaerobic mixed bacterial culture from an upflow anaerobic sludge blanket (UASB) bioreactor to convert blends of olive mill wastewaters (OMWs) with synthetic glucose medium or molasses into ethanol simultaneously with organic acids (OAs) was studied in the present work. All fermentations were conducted by free cells under non-aerated conditions at $37^{\circ} \mathrm{C}$ and the effect of OMWs concentration on ethanol and OAs production was investigated. The highest amount of bioethanol (14.7 $\mathrm{g} \mathrm{L}^{-1}$ ) was produced during fermentation of $45 \% \mathrm{v} / \mathrm{v}$ OMWs mixed with synthetic glucose medium $(5 \% \mathrm{w} / \mathrm{v})$ in only 28 hours. In mixtures of $30 \% \mathrm{v} / \mathrm{v}$ OMWs and molasses solution ( $3^{\circ} \mathrm{Be}$ ) $13.4 \mathrm{~g} \mathrm{~L}^{-1}$ of bioethanol were produced. Also, $16.2 \mathrm{~g} \mathrm{~L}^{-1}$ of succinic acid were produced, when $65 \% \mathrm{v} / \mathrm{v}$ OMWs mixed with synthetic glucose medium. Moreover, totally $11.6 \mathrm{~g} \mathrm{~L}^{-1}$ of varied OAs (succinic, malic, butyric and acetic) observed in mixtures of $35 \%$ OMWs with molasses. Finally, it has been shown that the ${ }^{14} \mathrm{C}$-labelled glucose uptake rate (GUR) by biomass was strongly correlated to fermentation rate.

Keywords: Olive mill wastewaters (OMWs), fermentation, culture of upflow anaerobic sludge blanket (UASB) bioreactor, molasses, ethanol, ${ }^{14} \mathrm{C}$-labeled glucose uptake rate.

\section{Introduction}

The olive mill wastewaters (OMWs) are produced during the extraction of olive oil via the three-phase method in modern centrifugal units. These wastes are very serious pollutants of aqueous receptors and soils mainly in Mediterranean countries (Aggelis et al., 2003; McNamara et al., 2008; Karaouzas et al., 2011), due to their high organic load. They are dark coloured solutions with characteristic odour and solid content up to $6 \% \mathrm{w} / \mathrm{v}$ the precise composition of which depends on the region of origin, the variety, the maturation of olives, etc. (Roig et al., 2006). Mainly, the OMWs contain phenolic compounds, tannins, polysaccharides, fatty acids, polyalcohols (LesageMeessen et al., 2001) and are characterized by a high polluting load of 14-110 and 41.4-130 $\mathrm{g} \mathrm{L}^{-1}$ in organic $\left(\mathrm{BOD}_{5}\right)$ and chemically required oxygen (COD) values respectively (Blika, 2009).
Over the last twenty years, many researchers have been studied with the possibility of decontaminating OMWs either by decomposing their components, such as polyphenols or by processing them to produce high added value products, e.g. ethanol, organic acids, enzymes etc. (Tsagaraki et al., 2006; Sarris et al., 2013, 2014). To this end, many physico-chemical and biotechnological processes have been proposed in order these wastes to be treated. Occasionally, oxidation, reverse osmosis, etc. (Scoma et al., 2011; Ena et al., 2012) as well as aerobic and anaerobic digestion, composting etc. (Tortosa et al., 2012; Dermeche et al., 2013) have been used for the OMWs decontamination. However, these wastes should be considered as a good substrate for a variety of bio-processes (Lanciotti et al., 2005; Zanichelli et al., 2007), which are generally low-cost, environmentally friendly and in line with Green Development.

The production of biofuels, such as ethanol, by fermentation of OMWs with microorganisms, has widely been investigated (Bellou et al., 2014; Mateo and Maicas, 2014). Often the mixing of OMWs with sugar-rich waste or by-products of the food industry, such as molasses, glucose etc. (Sarris et al., 2014; Dourou et al., 2016) was proposed for increasing the products yields.

In the present work the treatment of OMWs modified with molasses or glucose for the production of ethanol simultaneously with organic acids (OAs) by anaerobic fermentation was investigated. In an effort to discover new natural microorganisms capable of producing ethanol and OAs at high final concentrations or producing valuable compounds (i.e. succinic acid) in sufficient quantities, the mixed bacterial culture from an upflow anaerobic sludge blanket (UASB) bioreactor was used. According to our knowledge this is the first investigation indicating the use of the culture UASB for the valorization of OMWs or OMWs-based media for the production of ethanol and organic acids. The effect of OMWs concentration on the amount of ethanol and OAs produced during fermentation of OMWs blends by UASB mixed culture free cells was studied too. Finally, in the optimal fermentation conditions, the rate of ${ }^{14} \mathrm{C}$-labeled glucose uptake (GUR) by the cells of the microorganisms was determined. 


\section{Experimental}

\subsection{Culture and media}

The mixed bacterial anaerobic culture (sludge) was obtained from an UASB reactor and was grown under anaerobic conditions without any stirring at $37{ }^{\circ} \mathrm{C}$ in glucose or sucrose nutrient media containing: $50 \mathrm{~g} \mathrm{~L}^{-1}$ glucose or sucrose, $2.9 \mathrm{~mL}$ from an $\mathrm{NH}_{3}$ solution $25 \% \mathrm{w} / \mathrm{w}$ and $0.6 \mathrm{~mL}$ from a $\mathrm{H}_{3} \mathrm{PO}_{4}$ solution $50 \% \mathrm{v} / \mathrm{v}$ at a COD:N:P ratio of 100:5:1, $4 \mathrm{~g} \mathrm{~L}^{-1} \mathrm{NaHCO}_{3}$ and $4 \mathrm{~g} \mathrm{~L}^{-1}$ yeast extract, without $\mathrm{pH}$ adjustment. Every time about $12 \mathrm{~g} \mathrm{~L}^{-1}$ of prepared wet cells were separated by centrifugation.

The OMWs used for all fermentation experiments were obtained from a centrifugal olive mill of the agricultural association in Asopos (Lakonia, Greece). It contained about $15 \mathrm{~g} \mathrm{~L}^{-1}$ sugars (glucose, sucrose, fructose etc.), water, organic acids, fatty acids, phenolic compounds, etc. and had a $\mathrm{pH}$ value about 5.4. The wastes were centrifuged before the use for solids removal.

Molasses was obtained from the local Spiliopoulos Distillery S.A. (Patras, Achaia, Greece) and consists $(\% \mathrm{w} / \mathrm{w})$ of water (17-25), sucrose (30-40), glucose (4-9), fructose (5-12), polysaccharides-dextrin, pentosans, polyuronic acids (2-5), and inorganics. Before its use molasses was diluted with water to Baume density ( $\left.{ }^{\circ} \mathrm{Be}\right) 3$. All media were sterilized by autoclaving at $120{ }^{\circ} \mathrm{C}$ for $15 \mathrm{~min}$.

\subsection{Batch fermentation of OMWs mixtures}

The effect of OMWs concentration on ethanol and OAs production was studied by a series of fermentations conducted using sterilized mixtures $(250 \mathrm{~mL})$ composed of synthetic glucose medium $(5 \% \mathrm{w} / \mathrm{v})$ or diluted molasses $\left(3^{\circ} \mathrm{Be}\right)$ and OMWs in various concentrations $(20,30,45,55$ and $65 \% \mathrm{v} / \mathrm{v}$ ). About $3 \mathrm{~g}$ of free biomass cells were added along with every mixture into an Erlemeyer flask of $500 \mathrm{~mL}$ and allowed to ferment without air supply, stirring and $\mathrm{pH}$ adjustment at $37{ }^{\circ} \mathrm{C}$. Fermentation kinetics was monitored by Baume density and $\mathrm{pH}$ value measurements. Samples of the fermented broths were collected and stored at $-20{ }^{\circ} \mathrm{C}$ until further analysis. The produced ethanol and OAs were expressed as grams per $1 \mathrm{~L}$ of mixture. The recorded results were the mean value of three repeats.

At the beginning of some runs $1 \mathrm{~mL}$ of diluted labelled glucose [ARC 147 Glucose, D $\left(2{ }^{-14} \mathrm{C}\right), 50 \mu \mathrm{Ci} \mathrm{mL} \mathrm{m}^{-1}$ ] was added, as had been done in previous investigations (Soupioni et al., 1998) in order the GUR by cells of UASB mixed culture to be estimated.

\subsection{Residual sugars determination}

At the beginning and at the end of fermentation, sugars (i.e. glucose, sucrose, fructose etc.) were determined in the samples of OMWs mixtures. An HPLC system (LC-9A, Shimadzu Corporation, Kyoto, Japan) was used consisting of pump, column oven (CTO-10A), refractive index detector (RID-6A), and degassing unit (DGU-2A), and equipped with a Nucleogel ION-300 OA column. A solution $0.008 \mathrm{~N} \mathrm{H}_{2} \mathrm{SO}_{4}$ was used as mobile phase at a flow rate of $0.5 \mathrm{~mL} \mathrm{~min}^{-1}$ and 1-propanol (1\% v/v) was used as internal standard. Column temperature was $30^{\circ} \mathrm{C}$. Sample dilution was $0.4 \% \mathrm{v} / \mathrm{v}$, and the injection volume was $60 \mu \mathrm{L}$.

Sugar conversion was calculated by the following equation: (initial sugar - residual sugar)/initial sugar $\times 100$.

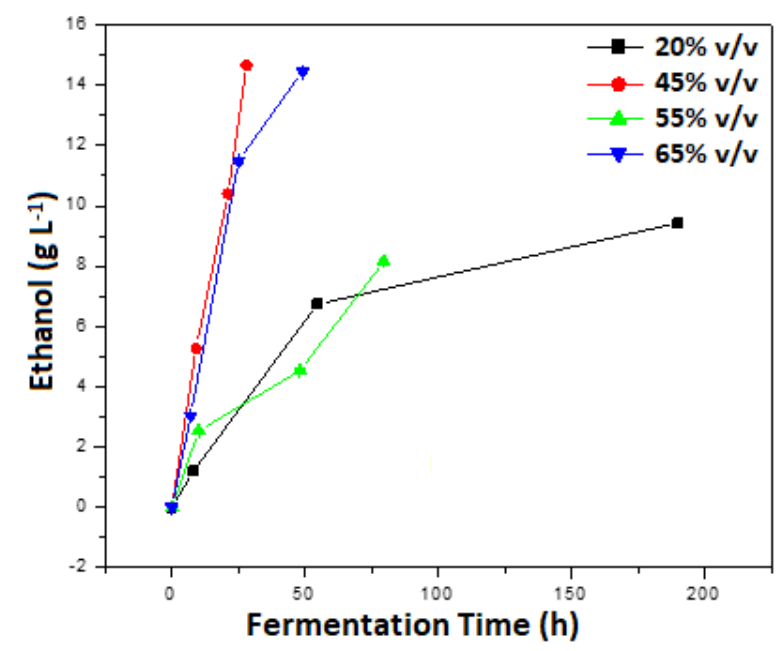

Figure 1. Ethanol concentration, during fermentation of OMWs mixtures with synthetic glucose medium $(5 \% \mathrm{w} / \mathrm{v})$ by free cells of an UASB mixed culture at $37^{\circ} \mathrm{C}$

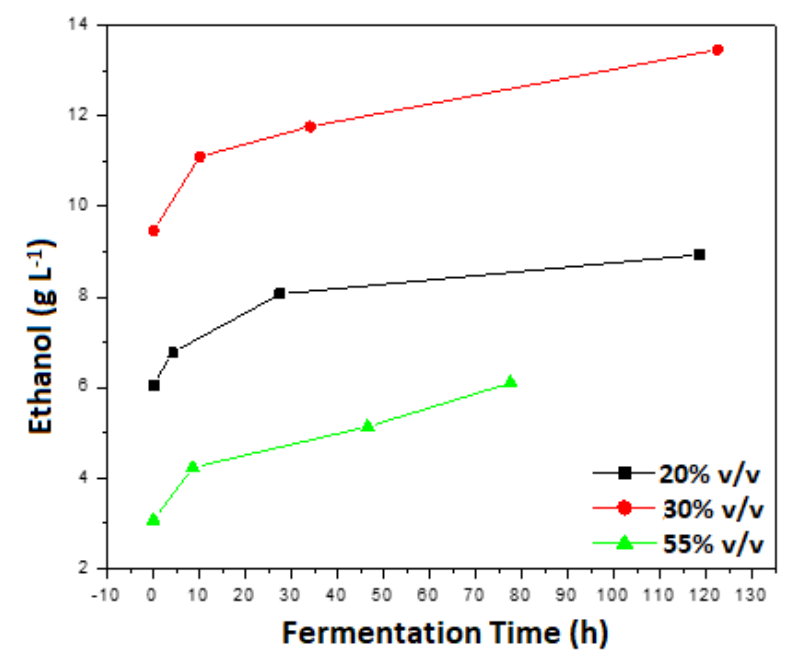

Figure 2. Ethanol concentration, during fermentation of OMWs mixtures with molasses solution $\left(3^{\circ} \mathrm{Be}\right)$ by free cells of an UASB mixed culture at $37^{\circ} \mathrm{C}$

\subsection{Ethanol determination}

Ethanol was determined by Gas Chromatography on a proper GC system (8A, Shimadzu) equipped with a FID detector, a HayeSep Q 80/100 mesh column ( $2 \mathrm{~m} \times 1 / 8$ ") (Teknokroma, Barcelona, Spain), and an integrator (C-R6A Chromatopack, Shimadzu). Helium was used as carrier gas at $20 \mathrm{~mL} \mathrm{~min}^{-1}$. The injection port and detector temperatures were 200 and $220{ }^{\circ} \mathrm{C}$. The column temperature was programmed from 80 to $180{ }^{\circ} \mathrm{C}$ at a rate of $16{ }^{\circ} \mathrm{C} \mathrm{min}{ }^{-1}$. Samples of $1 \mu \mathrm{L}$ were injected directly onto the column. Determinations were done by means of standard curves. 1-Butanol was used as internal standard at a concentration of $0.5 \%(\mathrm{v} / \mathrm{v})$. 

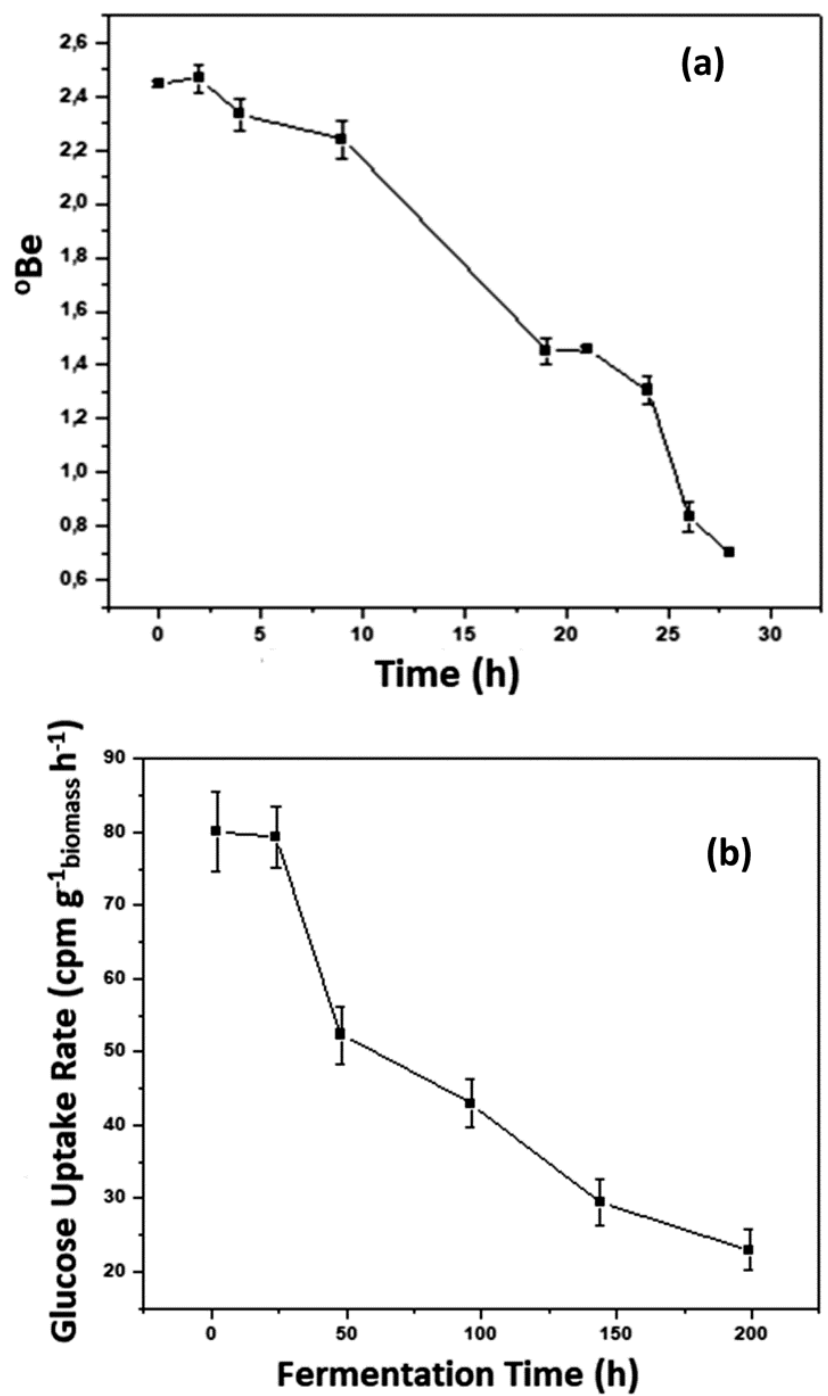

Figure 3. (a) Fermentation kinetics of sugar in $45 \% \mathrm{v} / \mathrm{v}$ OMWs mixed with synthetic glucose medium ( $5 \% \mathrm{w} / \mathrm{v})$ (b) Glucose uptake rate by free cells of an UASB mixed culture, observed at $37^{\circ} \mathrm{C}$

Table 1. Effect of OMWs concentration on kinetic parameters and average $(\mathrm{N}=3)$ concentrations $( \pm$ SD) of residual sugar, ethanol and OAs produced during fermentation of OMWs mixtures with synthetic glucose medium $(5 \% \mathrm{w} / \mathrm{v})$ or molasses solution ( $\left.{ }^{\circ} \mathrm{Be} 3\right)$ by free cells of an UASB mixed culture at $37^{\circ} \mathrm{C}$

\begin{tabular}{|c|c|c|c|c|c|c|c|c|c|c|}
\hline & $\begin{array}{l}\text { OMWs } \\
(\% \mathrm{v} / \mathrm{v})\end{array}$ & $\begin{array}{l}\text { Initial } \\
\text { sugar } \\
\text { (g L-1) }\end{array}$ & $\begin{array}{l}\text { Initial pH } \\
\text { value }\end{array}$ & $\begin{array}{l}\text { Ferment. } \\
\text { time (h) }\end{array}$ & $\begin{array}{l}\text { Residual } \\
\text { sugar } \\
\left(\mathrm{g} \mathrm{L}^{-1}\right)\end{array}$ & $\begin{array}{c}\text { Ethanol } \\
\left(\mathrm{g} \mathrm{L}^{-1}\right)\end{array}$ & $\begin{array}{c}\text { Ethanol } \\
\text { yield* } \\
\left(\mathrm{g} \mathrm{g}^{-1}\right)\end{array}$ & $\begin{array}{c}\text { Sugar } \\
\text { conversion } \\
(\%)\end{array}$ & $\begin{array}{l}\text { Final pH } \\
\text { value }\end{array}$ & $\begin{array}{c}\begin{array}{c}\text { Organic } \\
\text { acids } \\
\left(\mathrm{g} \mathrm{L}^{-1}\right)\end{array} \\
\text { Succinic } \\
\end{array}$ \\
\hline \multirow[t]{5}{*}{ Glucose } & 20 & $18.3 \pm 0.5$ & $8.7 \pm 0.04$ & 190 & $0.4 \pm 0.2$ & $9.4 \pm 0.05$ & 0.81 & 95.08 & $4.11 \pm 0.05$ & $4.00 \pm 0.20$ \\
\hline & 45 & $16.1 \pm 0.7$ & $7.71 \pm 0.03$ & 28 & $2.3 \pm 1.1$ & $14.7 \pm 0.05$ & 1.09 & 85.71 & $3.37 \pm 0.03$ & $12.5 \pm 0.20$ \\
\hline & 55 & $18.3 \pm 1.5$ & $8.00 \pm 0.03$ & 92 & $4.9 \pm 0.8$ & $8.15 \pm 0.08$ & 0.60 & 74.32 & $3.15 \pm 0.10$ & $13.7 \pm 0.10$ \\
\hline & 65 & $15.5 \pm 0.5$ & $6.64 \pm 0.03$ & 49 & $2.1 \pm 1.3$ & $14.5 \pm 0.05$ & 1.08 & 86.45 & $3.23 \pm 0.03$ & $16.2 \pm 0.40$ \\
\hline & & & & & & & & & & Total \\
\hline \multirow[t]{3}{*}{ Molasses } & 20 & $26.1 \pm 1.05$ & $8.82 \pm 0.03$ & 118.5 & $15.8 \pm 2.2$ & $8.93 \pm 0.05$ & 0.74 & 89.24 & $9.07 \pm 0.01$ & $2.05 \pm 0.1$ \\
\hline & 30 & $18.1 \pm 0.7$ & $8.91 \pm 0.06$ & 112.5 & $15.7 \pm 1.3$ & $13.4 \pm 0.05$ & 0.47 & 80.14 & $9.16 \pm 0.04$ & $2.50 \pm 0.3$ \\
\hline & 55 & $8.6 \pm 1.3$ & $9.01 \pm 0.03$ & 77.5 & $6.5 \pm 0.2$ & $6.10 \pm 0.1$ & 0.69 & 73.28 & $9.13 \pm 0.01$ & $6.65 \pm 0.1$ \\
\hline
\end{tabular}

* $g$ of ethanol per $g$ of converted sugar

\subsection{OAs determination}

Organic acids were determined by High Performance Liquid Chromatography (HPLC) on a Jasco LC-2000 Plus chromatograph equipped with an Aminex column (300 $\times 7.8 \mathrm{~mm}$ i.d., $9 \mu \mathrm{m}$ particle size; HPX-87H, Bio-Rad, Hercules, CA, USA) column thermostat (CO-2060 Plus
Intelligent, Jasco), quaternary gradient pump (PU-2089 Plus), autosampler (AS-2050 Plus Intelligent), photodiode array detector (MD-2018 Plus) operated at $210 \mathrm{~nm}$, and a hardware interface (LC-Net II/ADC Chromatography Data Solutions). Isocratic separation at $22{ }^{\circ} \mathrm{C}$ was performed with a solution $0.005 \mathrm{~N} \mathrm{H}_{2} \mathrm{SO}_{4}$ as mobile phase at a flow rate 
of $0.5 \mathrm{~mL} \mathrm{~min} \mathrm{~m}^{-1}$. Before analysis the samples were diluted $1 / 5$ and filtered by a membrane filter of $0.22 \mu \mathrm{m}$ pore size.

\section{6. ${ }^{14} \mathrm{C}$ labelled glucose determination}

The labelled glucose was fermented in the same way as the non active one. At various time intervals samples of $5 \mathrm{~mL}$ of the fermented broth were centrifuged, and the biomass was kept in plastic vials with $5 \mathrm{~mL}$ of liquid scintillation cocktail (Opti-Fluor, Perkin Elmer, Waltham, MA, USA). The ${ }^{14} \mathrm{C}$ within cells was measured by a Liquid Scintillation Analyzer TRI-CARB 1500 PACKARD connected to PC and recorder (DOT MATRIX PRINTER CITIZEN Swift 24). The resulted GUR were expressed in [cpm/(gbiomass.h)].

\subsection{Statistical methods and data analysis}

During OMWs mixtures fermentations the standard deviations (SD) of each of three recorded values for sugars, ethanol and OAs concentrations as well as GUR were calculated (Origin 8, Microcal Software Inc., Northampton, MA, USA). The data were analyzed using the analysis of variance technique. Significant differences between means were identified by one-way ANOVA. Statistical analyses were carried out using the computer software SPSS version 21.0 for Windows (SPSS Inc., Chicago, IL).

\section{Results and discussion}

The effect of OMWs concentration on the ethanol and the OAs amount produced during anaerobic fermentation of OMWs mixtures with synthetic glucose medium $(5 \% \mathrm{w} / \mathrm{v})$ or molasses solution $\left(3^{\circ} \mathrm{Be}\right.$ ) by free cells of mixed culture from an UASB bioreactor at $37{ }^{\circ} \mathrm{C}$ is shown in Figures 1 and 2 and Tables 1 and 2 .

Table 2. Effect of OMWs concentration on average $(\mathrm{N}=3)$ concentrations $( \pm S D)$ of OAs produced during fermentation of OMWs mixtures with molasses solution $\left(3^{\circ} \mathrm{Be}\right)$ by free cells of an UASB mixed culture at $37^{\circ} \mathrm{C}$ (Table 2)

\begin{tabular}{ccccc}
\hline $\begin{array}{l}\text { OMWs } \\
(\% \mathrm{v} / \mathrm{v})\end{array}$ & & \multicolumn{3}{c}{ Organic acids $\left(\mathrm{g} \mathrm{L}^{-1}\right)$} \\
\hline & Succinic & Malic & Acetic & Butyric \\
\hline 20 & - & $0.3 \pm 0.01$ & - & $1.8 \pm 0.1$ \\
\hline 30 & $2.2 \pm 0.3$ & $0.3 \pm 0.01$ & - & - \\
\hline 55 & - & - & $0.35 \pm 0.02$ & $6.3 \pm 0.1$ \\
\hline
\end{tabular}

The highest ethanol concentration (14.7 $\left.\mathrm{g} \mathrm{L}^{-1}\right)$ was observed during fermentation of $45 \% \mathrm{v} / \mathrm{v}$ OMWs mixed with synthetic glucose medium $(5 \% \mathrm{w} / \mathrm{v})$ in only $28 \mathrm{~h}$ (Figure 1, Table 1). Specifically, the ethanol concentration was significantly higher $(P<0.05)$ in the case of the $45 \% \mathrm{v} / \mathrm{v}$ OMWs glucose mixtures compared to that from fermentations of 20 or $55 \% \mathrm{v} / \mathrm{v}$ ones.

However, during fermentation of OMWs blends with molasses solution $\left(3^{\circ} \mathrm{Be}\right)$ significantly higher $(P<0.05)$ bioethanol amount $\left(13.4 \mathrm{~g} \mathrm{~L}^{-1}\right)$ produced when $30 \% \mathrm{v} / \mathrm{v}$ OMWs were used, compared with the 20 or $55 \%$ v/v OMWs (Figure 2, Table 1).

Concerning the OAs production is remarkable that only succinic acid was produced during fermentation of OMWs blends with synthetic glucose medium. Indeed, the highest succinic acid concentration (16.2 $\mathrm{g} \mathrm{L}^{-1}$ ) was observed in 49 h, when $65 \%$ v/v OMWs mixed with synthetic glucose medium (5\% w/v) (Table 1). This was significantly higher ( $P$ $<0.05)$ compared to the succinic acid concentration from fermentation of $20 \% \mathrm{v} / \mathrm{v}$ but near that in the case of the $45 \% \mathrm{v} / \mathrm{v}\left(12.5 \mathrm{~g} \mathrm{~L}^{-1}\right)$ and 55\% v/v (13.7 $\left.\mathrm{g} \mathrm{L}^{-1}\right)$ OMWs glucose mixtures. As it is known, in 2004, the succinate was placed on the US Department of Energy's list of top 12 platform chemicals from biomass [https://www.nrel.gov./docs/fyo4osti/35523.pdf]. Also, succinic acid is a precursor to some biodegradable polymers, resins or chemical solvents, used as food additive and dietary supplement etc.

Moreover, low concentrations of varied OAs (succinic, malic, butyric and acetic) were observed in mixtures of 20, 30 and 55\% v/v OMWs with molasses (Table 2).

Figures $3 a$ and $b$ show the fermentation kinetics of sugar and glucose uptake rate by free cells of an UASB mixed culture in $45 \% \mathrm{v} / \mathrm{v}$ OMWs mixed with synthetic glucose medium $(5 \% \mathrm{w} / \mathrm{v})$ observed at $37{ }^{\circ} \mathrm{C}$, respectively. It is obvious that GUR was strongly related to fermentation rate as previous reported for the lactose uptake rate by kefir (Golfinopoulos et al., 2009; 2011; 2012; Soupioni et al., 2013) and the produced ethanol did not affect the glucose uptake by mixed culture.

\section{Conclusions}

The low cost anaerobic mixed bacterial culture from an UASB bioreactor contains suitable microorganisms of producing ethanol simultaneously with OAs during fermentation of OMWs blends with synthetic glucose medium $(5 \% \mathrm{w} / \mathrm{v})$ or molasses solution $\left(3^{\circ} \mathrm{Be}\right)$ at $37^{\circ} \mathrm{C}$. The highest ethanol concentration was recorded for $45 \% \mathrm{v} / \mathrm{v}$ OMWs mixed with glucose medium in $28 \mathrm{~h}$ fermentation time and in that case the GUR was strongly correlated to fermentation rate. Valuable succinic acid was the unique organic acid produced during fermentation of OMWs blends with glucose medium and its highest amount was observed for $65 \%$ v/v OMWs in $49 \mathrm{~h}$. Lower ethanol and OAs concentrations (succinic, malic, butyric and acetic) were obtained using molasses solution in about the same volume for the blends preparation.

Therefore, bioconversion of OMWs sugars by free cells of $U A S B$ culture during the aforementioned processes could be used by olive mills to produce fast saleable products, whilst simultaneously reduce the organic load of their wastes.

\section{References}

Aggelis G., Iconomou D., Christou M., Bokas D., Kotzailias S., Christou G., Tsagou V. and Papanikolaou S. (2003), Phenolic removal in a model olive oil mill wastewater using Pleurotus ostreatus in bioreactor cultures and biological evaluation of the process, Water Research, 37, 3897-3904.

Bellou S., Makri A., Sarris D., Michos K., Rentoumi P., Celik A., Papanikolaou S. and Aggelis G. (2014), The olive mill wastewater as substrate for single cell oil production by Zygomycetes, Journal of Biotechnology, 170, 50-59. 
Blika P. (2009), Biotechnological Methods of Olive Mill Wastewaters Processing, Ph.D. Thesis, Department of Chemical Engineering, University of Patras.

Dermeche S., Nadour M., Larroche C., Moulti-Mati F. and Michaud P. (2013), Olive mill wastes: Biochemical characterizations and valorization strategies, Process Biochemistry, 48, 15321552.

Dourou M., Kancelista A., Juszczyk P., Sarris D., Bellou S., Triantaphyllidou I.-E., Rywinska A., Papanikolaou S. and Aggelis G. (2016), Bioconversion of olive mill wastewater into high-added value products, Journal of Cleaner Production, 139, 957-969.

Ena A., Pintucci C. and Carlozzi P. (2012), The recovery of polyphenols from olive mill waste using two adsorbing vegetable matrices, Journal of Biotechnology, 157, 573-577.

Golfinopoulos A., Papaioannou L., Soupioni M., and Koutinas A.A. (2009), lactose uptake rate by kefir yeast using ${ }^{14} \mathrm{C}$-labelled lactose to explain kinetic aspects in its fermentation, Bioresourse Technology, 100 (21), 5210-5213.

Golfinopoulos A., Kopsahelis N., Tsaousi K., Koutinas A.A. and Soupioni M. (2011), Research perspectives and role of lactose uptake rate revealed by its study using ${ }^{14} \mathrm{C}$-labelled lactose in whey fermentation, Bioresource Technology, 102(5), 42044209.

Golfinopoulos A., Soupioni M., Kopsahelis N., Tsaousi K. and Koutinas A.A. (2012), Lactose uptake rate measurements by ${ }^{14} \mathrm{C}$-labelled lactose reveals promotional activity of porous cellulose in whey fermentation by kefir, Food Chemistry, 134, 1973-1981.

Karaouzas I., Skoulikidis N.T., Giannakou U. and Albanis T.A. (2011), Spatial and temporal effects of olive mill wastewaters to stream macroinvertebrates and aquatic ecosystems status, Water Research, 45, 6334-6346.

Lanciotti R., Gianotti A., Baldi D., Angrisani R., Suzzi G., Mastrocola D. and Guerzoni M.E. (2005), Use of Yarrowia lipolytica strains for the treatment of olive mill wastewater, Bioresource Technology, 96, 317-322.

Lesage-Meessen L., Navarro D., Maunier S., Sigoillot J.C., Lorquin J., Delattre M., Simon J.L., Asther M. and Labat M. (2001), Simple phenolic content in olive oil residues as a function of extraction systems, Food Chemistry, 75, 501-507.

Mateo J.J. and Maicas S. (2014), Valorization of winery and oil mill wastes by microbial technologies, food Research International, 73, 13-25.

McNamara C.J., Anastasiou C.C., O'Flaherty V. and Mitchell R. (2008), Bioremediation of olive mill wastewater. International Biodeterioration \& Biodegradation, 61, 127-134.

Mert B.K., Yonar T., Kilic M.Y. and Kestioğlu K. (2010), Pre-treatment studies on olive oil mill effluent using physicochemical, Fenton and Fenton-like oxidations processes, Journal of Hazardous Materials, 174, 122-128.

Roig A., Cayuela M.L. and Sanchez-Monedero M.A. (2006), An overview on olive mill wastes and their valorisation methods, Waste Management, 26, 960-969.

Sarris D., Giannakis M., Philippoussis A., Komaitis M., Koutinas A.A. and Papanikolaou S. (2013), Conversions of olive mill wastewater-based media by Saccharomyces cerevisiae through sterile and non-sterile bioprocesses, Journal of Chemical Technology and Biotechnology, 88, 958-969.

Sarris D., Matsakas L., Aggelis G., Koutinas A.A. and Papanikolaou S. (2014), Aerated vs non-aerated conversions of molasses and olive millwastewaters blends into bioethanol by Saccharomyces cerevisiae under non-aseptic conditions, Industrial Crops and Products, 56, 83-93.

Scoma A., Bertin L., Zanaroli G., Fraraccio S. and Fava F. (2011), A physicochemical biotechnological approach for an integrated valorization of olive mill wastewater, Bioresource Technology, 102, 10273-10279.

Soupioni M., Golfinopoulos A., Kanellaki M. and Koutinas A.A. (2013), Study of whey fermentation by kefir immobilized on low cost supports using ${ }^{14} \mathrm{C}$-labelled lactose, Bioresource Technology, 145, 326-330.

Soupioni M., Polichroniadou E., Tokatlidou M., Kanellaki M. and Koutinas A.A. (1998), Glucose uptake rate by Saccharomyces cerevisiae, in the presence of promoters of alcoholic fermentation, using ${ }^{14} \mathrm{C}$-labelled glucose, Biotechnology Letters, 20(5), 495-497

Tortosa G., Alburquerque J.A., Ait-Baddi G. and Cegarra J. (2012), The production of commercial organic amendments and fertilisers by composting of two-phase olive mill waste ("alperujo"), Journal of Cleaner Production, 26, 48-55

Tsagaraki E., Lazarides H.N. and Petrotos K.B. (2006), Olive mill wastewater treatment, In: Utilization of By-Products and Treatment of Waste in the Food Industry, Springer US edition, p. 133-157.

Zanichelli D., Carloni F., Hasanaj E., D’Andrea N., Filippini A. and Setti L. (2007), Production of ethanol by an integrated valorization of olive oil byproducts. The role of phenolic inhibition, Environmental Science and Pollution Research, 14, 5-6, https://www.nrel.gov./docs/fyo4osti/35523.pdf (last accessed 05-10-2018). 